\title{
MORFOFONEMIK DALAM TULISAN ARTIKEL KARYA SISWA KELAS XII SMK MULTIMEDIA TUMPANG
}

\author{
Lailatu Fitriah, Hari Windu Asrini \\ Magister Pendidikan Bahasa Indonesia Universitas Muhammadiyah Malang \\ Jalan Raya Tlogomas No. 246 Tlogomas, Kota Malang, Jawa Timur, Indonesia \\ zahratullaila@webmail.umm.ac.id
}

\begin{abstract}
ABSTRAK: Kompetensi menulis artikel pada kelas XII jenjang SMK sesuai dengan kurikulum 2013 KI 3.47 dan KD 4.47. Penelitian ini difokuskan pada morfofonemik dalam artikel karangan siswa kelas XII SMK Multimedia Tumpang yaitu pada proses penambahan fonem, pelesapan fonem, peluluhan fonem, perubahan fonem dan pergeseran fonem. Penelitian ini menggunakan pendekatan deskriptif kualitatif dan termasuk jenis penelitian analisis teks. Hasil penelitian ini menunjukkan bahwa morfofonemik dalam artikel karangan siswa kelas XII SMK Multimedia Tumpang, 1). Hanya terdapat penambahan fonem, pelesapan fonem, peluluhan fonem, perubahan fonem serta tidak ditemukan pergeseran fonem. 2). Tidak semua proses afiksasi mengakibatkan perubahan, diantara proses afiksasi yang menyebabkan perubahan adalah prefiksasi /ber-/, prefiksasi /me-/ dan klofiksasi /me-kan/, /me-i/. Prefiksasi /pe-/ dan konfiksasi /pe-an/,prefiksasi /per-/ dan konfiksasi /per-an/, prefiksasi/ter-/. 3). Kerancuan morfofonemik sebanyak 5 kata. 4). tidak ditemukan perubahan fonem pada proses sufiksasi /-an/.

KATA KUNCI: Morfofonemik, artikel, afiksasi, kurikulum 2013
\end{abstract}

\section{MORPHONEMICS IN THE WRITING OF STUDENTS 'ARTICLES CLASS XII SMK}

ABSTRACT: Writing competence in class XII at SMK according to the 2013 curriculum, KI 3.47 and KD 4.47. This research is focused on the morphophonemic in the articles written by the XII grade students of SMK Multimedia Tumpang, namely the process of phoneme appearance, phoneme impingement, phoneme pulsation, phoneme change and phoneme shift. This research uses a qualitative descriptive approach and is a type of text analysis research. The results of this study indicate that the morphophonemic in the article written by class XII students of SMK Multimedia Tumpang, 1). There were only phoneme occurrences, phoneme impingement, phoneme pulsation, phoneme change and no phoneme shift was found. 2). Not all affixation processes result in morphophonemic, among the affixation processes that cause phoneme changes are prefixation / ber- /, prefix / me / and cllofixation / me -kan /, / me-i /. Prefixation / reposition / and fixation / message /, prefix / per- / and confixation / per -an /, prefixation / ter- /. 3). Morphophonemic confusion is 5 words. 4). no morphophonemic found in the / -an / suffixation process.

KEY WORDS: Morphophonemic, articles, affixation, 2013 curriculum

\begin{tabular}{cccc}
\hline Diterima: & Direvisi: & Disetujui: & Dipublikasi: \\
2021-01-05 & 2021-01-27 & 2021-02-04 & 2021-03-28 \\
Pustaka & fitriah, 1., \& Asrini, H. (2021). MORFOFONEMIK DALAM TULISAN ARTIKEL KARYA \\
& $\begin{array}{l}\text { SISWA KELAS XII SMK. Fon : Jurnal Pendidikan Bahasa dan Sastra Indonesia, 17(1), 85-96. } \\
\text { doi:https://doi.org/10.25134/fjpbsi.v17i1.3888 }\end{array}$ \\
\hline
\end{tabular}

\section{PENDAHULUAN}

Menulis merupakan salah satu dari kompetensi bahasa yang wajib dipelajari di semua jenjang pendidikan, dari pendidikan dasar sampai pendidikan tinggi. Menulis tidak hanya melatih siswa untuk mengembangkan pengetahuannya, melainkan melatih kekritisan siswa dalam menyikapi suatu permasalahan yang marak di tengah masyarakat. Karangan siswa yang berisi ide atau gagasan dan memiliki tujuan tertentu salah satunya berbentuk artikel. Penulisan artikel harus memperhatikan kohesi dan koherensi serta tata bahasa baku bahasa Indonesia, sehingga tulisan tersebut runtut serta mudah dipahami. 
Materi menulis artikel pada pelajaran Bahasa Indonesia di SMK sesuai dengan kurikulum 2013. Tepatnya pada kompetensi inti nomor 3.47 dan kompetensi dasar 4.47, artinya kompetensi tersebut merupakan salah satu kemampuan yang harus dikuasai siswa pada jenjang tersebut. Namun dalam praktiknya menulis artikel masih banyak kesalahan, seperti kesalahan morfologi, tanda baca, dan tatanan sintaksis. Proses morfologi selalu mengiringi penulisan kata, karena berhubungan dengan proses pembentukan kata secara gramatikal. Proses morfologi secara gramatikal dapat mengubah makna kata, oleh karena itu morfologi lebih ke desain struktur kata dan elemen kata (Bloomfield, 1995). Kata merupakan unsur terkecil dari bahasa yang dapat disimbolkan atau diverbalkan, serta berupa keutuhan ide, perasaan yang digunakan dalam berbahasa (Rizky,2019). Sedangkan ilmu morfologi merupakan salah satu bidang linguistik yang mengkaji hubungan morfem dengan morfem lainnya untuk membentuk sebuah kata (Abidin, 2019). Kata dapat dikatakan sebagai fondasi bahasa karena merupakan unsur pembentuk yang sangat penting, misalkan kata virus, terkontaminasi, menarik, mengemas dan lain sebagainya. Proses morfologi juga mengakibatkan terjadinya perubahan fonem yang disebut dengan morfofonemik. Penulisan morfofonemik pada karangan siswa dapat memperjelas arti dan maksud, sehingga gagasan yang ingin disampaikan dalam tulisan mudah dipahami.

Menurut Ramlan, perubahan fonem mempelajari tentang perubahan yang muncul akibat adanya pertemuan antara suatu morfem dengan morfem lainnya (Hasan, 2002). Perubahan fonem juga dapat dikatakan sebagai transformasi fonem menjadi fonem lainnya, yang sesuai dengan fonem awal kata tersebut (Arifin, 2017). Proses perubahannya dapat terjadi secara statis dan dinamis, serta dapat berlangsung secara otomatis dan manual (Parera, 2007). Morfofonemik hanya terjadi pada proses morfologi yang berupa afiksasi. Menurut Kridalaksana (dalam Ingguoe, 2015), afiksasi merupakan perubahan bentuk leksem menjadi jenis tertentu sehingga mempunyai makna yang berubah. Proses afiksasi yang mengakibatkan perubahan yaitu penambahan prefik /ber/, prefiks /me-/ dan klofiks /me-kan ,/me-i/, prefiks /pe-/, konfiks /pe-an/, prefiks /per/ konfiks /per-an/, sufiks /-an/ dan prefiks /ter-/. Terdapat beberapa proses perubahan, diantaranya penambahan fonem, pelesapan fonem, peluluhan fonem, perubahan fonem, pergeseran fonem, dan pengekalan fonem (Chaer,2008).

Penambahan fonem, terjadi karena fonem yang muncul disebabkan karena proses morfologi. Misalkan pada kata membatu, prefiks /me-/ yang mengikuti kata dasar/batu/ akan menimbulkan bunyi sengau $/ \mathrm{m} /$ yang awalnya tidak ada. Pelesapan fonem, dikarenakan proses morfologi menyebabkan fonem yang awalnya tampak menjadi hilang. Misalkan pada kata berenang, prefiks /ber-/ yang mengikuti kata /renang/ maka bunyi /r/ pada prefiks tersebut dilesapkan atau dihilangkan. Peluluhan fonem, karena proses morfologi yang menyebabkan sebuah fonem yang melekat menjadi luluh dan disenyawakan dengan fonem lain. Seperti pada kata menyimak, perfiks /me-/ yang mengikuti kata dasar/simak/ maka fonem /s/ pada kata dasar tersebut luluh dan berganti dengan bunyi nasal /ny/. Perubahan fonem, karena proses morfologi menyebabkan bunyi fonem berubah. Misalkan pada kata belajar, prefiks /ber-/ yang mengikuti kata dasar ajar maka bunyi $/ \mathrm{r} /$ pada prefiks tersebut berubah menjadi $/ 1 /$. Pergeseran fonem, karena proses morfologi menyebabkan fonem bergeser ke dalam suku kata yang lainnya. Misalkan pada kata timbunan, fonem $/ \mathrm{n} /$ pada kata dasar /timbun/ 
bergeser ke suku kata lainnya karena mendapat tambahan sufiks /-an/, proses tersebut menjadi Timbunan - tim-bunan.

Pengekalan fonem, dikarenakan, pada saat proses morfologi, tidak ada fonem yang berubah. Misalkan pada kata beranak, prefik /ber-/ yang melekat pada kata dasar anak tidak mengalami perubahan atau bersifat kekal.

Fonem adalah bunyi bahasa yang membedakan makna kata (Alex, 2018). Oleh karena itu keberadaan fonem dalam morfofonemik dapat membedakan prosesnya. Seperti pada artikel yang ditulis oleh siswa kelas XII SMK Multimedia Tumpang, dalam setiap katanya tidak akan lepas dari proses perubahan fonem. Hal tersebut terjadi karena adanya fonem yang membedakan makna di setiap katanya. Menulis teks artikel dipilih karena menulis artikel memerlukan ketepatan penulisan kata. Tidak hanya itu, diperlukan proses bernalar menjadi kalimat runtut hingga akhirnya menjadi wacana yang berisi ide atau gagasan penulisnya.

Penelitian ini hanya difokuskan pada proses morfofonemik pada teks artikel yang ditulis oleh siswa. Objek penelitian adalah siswa kelas XII SMK Multimedia Tumpang jurusan pemasaran, multimedia, keperawatan, farmasi dan perhotelan. Penulisan perubahan fonem dalam teks artikel karangan siswa SMK Multimedia Tumpang perlu diteliti untuk melihat kemampuan siswa dalam mengaplikasikan kaidah morfofonemik dalam menulis artikel tersebut. Mengingat terdapat enam proses morfofonemik yang dapat mempengaruhi fonem, dan harus diperhatikan siswa dalam proses menulis.

Banyak penelitian yang membahas perihal perubahan fonem, namun perbedaan penelitian ini terdapat pada objek penelitian yang berupa artikel yang dibuat oleh siswa jenjang SMK.
Penelitian sebelumnya mengenai perubahan fonem pernah dilakukan diantaranya oleh Fatmawati (2014) dengan judul Analisis Morfofonemik Novel Kadurakan ing Kidul Dringu Karya Suparto Brata. Hasil penelitian tersebut menyebutkan proses perubahan dalam novel Kadurakan Ing Kidul Drangu karya Suparto Brata dibagi menjadi tiga yaitu: perubahan fonem, penambahan fonem, dan penghilangan fonem. Paryono (2018) penelitian berjudul Morfofonemik Bahasa Jawa Dialek Banyumas. Hasil penelitian menyebutkan, secara umum perubahan fonem bahasa Jawa Dialek Banyumas pada proses afiksasi menyebabkan peristiwa fonemis. Peristiwa tersebut yaitu perubahan fonem, penambahan fonem, dan penghilangan fonem. Adapun perubahan yang terjadi pada modifikasi intern berupa pelesapan/penghilangan suku awal kata pada bentuk dasar tersebut dan berupa penyisipan atau penambahan vokal /u/. Wijaya (2020) yang berjudul Morfofonemik Kata Benda dan Kata kerja Bahasa Jawa Dialek Surabaya dalam Acara Pojok Kampung JTV. Hasil penelitian menyebutkan, dalam bahasa Jawa dialek Surabaya pada Acara Pojok Kampung JTV menimbulkan peristiwa fonemis. peristiwa tersebut berupa perubahan fonem, penambahan fonem, dan penghilangan fonem. Mutiadi (2015) dengan judul Analisis Kesalahan Morfologi dan Sintaksis pada Pidato Presiden Joko Widodo Periode Januari. Hasil penelitian diantaranya menyebutkan bahwa kesalahan morfologi pada pidato Presiden Joko widodo karena penghilangan imbuhan misalkan kata mengalami menjadi ngalami. Selain itu terdapat penyingkatan morfem. Penelitian berikutnya dilakukan oleh Al Muthi'ah (2019) dengan judul Morfofonemik dalam Teks Pidato Karangan Siswa Kelas XII SMA Negeri 1 Durenan. Hasil penelitian menyebutkan bahwa perubahan fonem dalam teks pidato karangan siswa kelas 
XII SMA Negeri 1 Durenan meliputi (1) perubahan fonem, (2) penambahan fonem, dan (3) penghilangan fonem. Penelitian selanjutnya dilakukan oleh Alexandria (2016) dengan judul Proses Morfofonemik Kata Berafiks Dalam Rubrik Percikan Majalah Gadis. Hasil penelitian menyebutkan ditemukan 344 kata berafiks dan 12 pola perubahan.

Kesamaan penelitian ini dengan penelitian sebelumnya adalah sama-sama menelaah tentang proses morfologi, namun lebih difokuskan pada proses perubahan fonem. Sedangkan perbedaan penelitian ini dengan penelitian sebelumnya adalah pada fokus dan objek penelitian. Penelitian ini memfokuskan proses morfofonemik pada artikel karangan siswa yang mencakup penambahan fonem, pelesapan fonem, peluluhan fonem, perubahan fonem, pergeseran fonem dan pengekalan fonem.

Tujuan dari penelitian ini adalah untuk mengidentifikasi proses perubahan fonem yang meliputi penambahan fonem, pelesapan fonem, peluluhan fonem, perubahan fonem, pergeseran fonem dan pengekalan fonem yang terdapat dalam teks artikel karangan siswa kelas XII SMK Multimedia Tumpang.

\section{METODE}

Penelitian ini menggunakan metode deskriptif kualitatif. Pendekatan penelitian ini dengan melakukan studi kasus pada bulan Desember tahun 2020 di SMK Multimedia Tumpang. Data merupakan semua kata yang terdapat morfofonemik pada artikel karya siswa dengan purposive sampling. Sumber data yang adalah artikel yang diambil dari kelas XII jurusan Pemasaran, Multimedia, Farmasi, Keperawatan, dan Perhotelan. Pengumpulan data dengan menggunakan teknik dokumentasi. Beberapa kriteria yang digunakan peneliti untuk menyeleksi sumber data diantaranya 1) Artikel harus asli karangan siswa sendiri karena itu peneliti melakukan pengecekan keaslian. 2) Tulisan siswa tampak jelas dan terbaca. 3) Adanya kecocokan antara judul dengan isi. 4) Mempunyai struktur artikel yang runtut dari orientasi, isi dan reorientasi.

Analisis data dilakukan dengan mengadopsi analisis menurut Miles dan Huberman yaitu pola umum dengan model alir (Yusuf ,2017). Pola alir di awali dengan mereduksi data yaitu mengelompokkan, memilih, menyederhanakan data dan memberi kode. Pengkodean dilakukan untuk menunjukkan letak kalimat dalam artikel yang mengalami morfofonemik. Seperti kode (ar) berarti artikel, kode (prg) berarti paragraf, serta kode angka 1 sampai 10 menunjukkan urutan. Selanjutnya display data yaitu informasi yang tersusun untuk diambil kesimpulannya dan tindakan selanjutnya, dan terakhir memverifikasi data dengan menarik kesimpulan.

\section{HASIL DAN PEMBAHASAN}

Berdasarkan data yang diperoleh, terdapat sebanyak 122 kata dalam artikel karangan siswa kelas XII yang mengamali perubahan fonem. Kata tersebut mengalami perubahan pada beberapa proses afiksasi, seperti prefiksasi /ber-/, prefiksasi /me-/, klofiks /me-kan/ dan /me$\mathrm{i} /$, prefiksasi /pe-/, konfiksasi /pe-an/, prefiksasi /per-/, konfiksasi /per-an/, dan prefiksasi /ter-/. Selain itu, terdapat 5 kata yang mengalami kerancuan morfofonemik.

Perubahan fonem pada artikel karangan siswa kelas XII SMK Multimedia Tumpang sangat mendominasi. Perubahan umumnya disebabkan karena adanya proses afiksasi, seperti penambahan prefiks /ber-/, prefiks /me-/ (termasuk klofiks me-kan dan $m e-i)$, prefiks /pe-/ ,prefiks /per-/, prefiks /ter/, penambahan konfiks /pe-an/, dan konfiks /per-an/. Perubahan pada proses afiksasi dapat menyebabkan enam jenis perubahan yaitu penambahan fonem, 
pelesapan fonem, peluluhan fonem, perubahan fonem, dan pergeseran fonem dan pengekalan fonem. Prubahan fonem pada proses afiksasi dalam artikel karangan siswa dapat dilihat pada tabel di bawah ini.

Tabel 1. Afiksasi dan perubahan fonem

\begin{tabular}{|c|c|c|}
\hline Afiksasi & $\begin{array}{l}\text { Perubahan } \\
\text { Fonem }\end{array}$ & Jumlah kata \\
\hline $\begin{array}{l}\text { Prefiks } \\
\text { /ber-/ }\end{array}$ & $\begin{array}{l}\text { Pelesapan } \\
\text { Perubahan } \\
\text { Mengekalan }\end{array}$ & $\begin{array}{l}0 \text { kata } \\
1 \text { kata } \\
18 \text { kata }\end{array}$ \\
\hline $\begin{array}{l}\text { Prefiks } \\
\text { /me-/ } \\
\text { klofiks } \\
\text { /me-kan/ } \\
\text { dan /me- } \\
\text { i/ }\end{array}$ & $\begin{array}{l}\text { Pengekalan } \\
\text { Penambahan } \\
\text { Peluluhan }\end{array}$ & $\begin{array}{l}10 \text { kata } \\
28 \text { kata } \\
27 \text { kata }\end{array}$ \\
\hline $\begin{array}{l}\text { Prefiks } \\
\text { /pe-/ dan } \\
\text { konfiks } \\
\text { /pe-an/ }\end{array}$ & $\begin{array}{l}\text { Pengekalan } \\
\text { Penambahan } \\
\text { Peluluhan }\end{array}$ & $\begin{array}{l}0 \text { kata } \\
6 \text { kata } \\
10 \text { kata }\end{array}$ \\
\hline $\begin{array}{l}\text { Prefiks } \\
\text { /per/ dan } \\
\text { Konfiks } \\
\text { /per-an/ }\end{array}$ & $\begin{array}{l}\text { Pelesapan } \\
\text { Perubahan } \\
\text { Pengekalan }\end{array}$ & $\begin{array}{l}1 \text { kata } \\
0 \text { kata } \\
5 \text { kata }\end{array}$ \\
\hline $\begin{array}{l}\text { Prefiks } \\
\text { /ter-/ }\end{array}$ & $\begin{array}{l}\text { Pelesapan } \\
\text { Perubahan } \\
\text { Pengekalan }\end{array}$ & $\begin{array}{l}0 \text { kata } \\
0 \text { kata } \\
16 \text { kata }\end{array}$ \\
\hline $\begin{array}{l}\text { Prc } \\
\text { penamba } \\
\text { /ter-/ se } \\
\text { mengalar } \\
\text { mengakit } \\
\text { penamba } \\
\text { fonem } \\
\text { awalan /p } \\
\text { /me-i/ de } \\
\text { mengalar } \\
\text { penamba }\end{array}$ & $\begin{array}{l}\text { ses prefi } \\
\text { lan awalan /b } \\
\text { ta konfiks /per } \\
\text { i perubahan } \\
\text { atkan pelep } \\
\text { lan fonem } / r / \text {, } \\
\text { \% Sedangkan } \\
e-/, / m e-/, \text { serta } \\
\text { n konfiks /pe } \\
\text { i perubahan y } \\
\text { lan, peluluhan. }\end{array}$ & $\begin{array}{l}\text { si pada } \\
\text { /per-/, dan } \\
\text { sama -sama } \\
\text { em } / r / \text { yang } \\
\text { n fonem /r/, } \\
\text { pengekalan } \\
\text { penambahan } \\
\text { iks /me-kan/, } \\
\text { sama-sama } \\
\text { pengekalan, }\end{array}$ \\
\hline
\end{tabular}

\section{Morfofonemik Prefiks /ber/ pada Artikel Karangan Siswa}

Morfofonemik prefiks /ber-/ yang terdapat dalam artikel karangan siswa kelas XII SMK Multimedia Tumpang yaitu kata belajar, beristirahat, bertatap, bermasalah, berkembang, bergantung, berasal, bergizi, berjalan, berbagai, bersaing, berbagai, berbahaya, berinteraksi, berkumpul, beretika, bersentuhan. Proses afiksasi pada katakata tersebut menyebabkan perubahan fonem $/ r /$ yang terdiri dari perubahan fonem, dan pengekalan fonem. Pada proses perubahan prefiks /ber/ tidak ditemukan kata yang mengalami pelepasan fonem $/ \mathrm{r} /$. Contoh kata yang mengalami perubahan fonem $/ \mathrm{r} / \mathrm{pada}$ Prefiks /ber-/ terdapat dalam tabel di bawah ini.

Tabel 2. Morfofonemik prefiks /ber-/

\begin{tabular}{lll}
\hline $\begin{array}{l}\text { Perubahan } \\
\text { fonem }\end{array}$ & Kata & $\begin{array}{l}\text { Proses } \\
\text { bentukan }\end{array}$ \\
\hline Perubahan & belajar & ber-ajar \\
\hline Pengekalan & berbagai & ber-bagai \\
& berbahaya & $\begin{array}{l}\text { ber-bahaya } \\
\text { berasal }\end{array}$ \\
& ber-asal \\
& bergizi & ber-gizi \\
bervariasi & ber-variasi \\
\hline
\end{tabular}

Perubahan pada proses prefiksasi /ber-/ dapat dikatakan sebagai proses yang tidak produktif, karena perubahan tersebut hanya berpengaruh pada beberapa kata dasar dan dapat dihitung dengan jari. Berikut contoh kalimat dalam artikel yang terdapat perubahan fonem /ber-l.

\section{Contoh 1}

Meskipun terpaksa masyarakat harus mulai belajar mematuhi protokol kesehatan. (ar8/prg/04)

Kalimat pada contoh 1, terdapat kata belajar yang mengalami perubahan fonem $/ r /$ pada prefiks /ber-/. Kata belajar berasal dari kata dasar ajar yang mendapatkan prefiksasi /ber-/, namun proses tersebut mengakibatkan fonem $/ r /$ yang melekat pada morfem /ber-/ berubah menjadi fonem $/ l /$ sehingga tidak dibaca berajar namun dibaca belajar.

\section{Contoh 2}


Tahun 2020 ini sedang marak virus yang sudah banyak menghilangkan nyawa di berbagai belahan dunia.(ar1/prg/1)

Mengingat virus ini sangat berbahaya, maka negara harus segera melakukan penanganan. ( $\operatorname{ar} 1 / \mathrm{prg} / 3)$

Virus korona ini berasal dari Wuhan China. (ar2/prg/5)

Contoh 2 pada kalimat pertama, kedua, dan ke tiga terdapat kata berafiks /ber-/ yaitu berbagai, berbahaya, berasal. Kata berbagai berasal dari kata dasar bagai, kata berbahaya berasal dari kata dasar bahaya, kata berasal berawal dari kata dasar asal. Kata-kata dasar tersebut mendapatkan prefiksasi /ber-/, namun fonem $/ r /$ yang melekat pada morfem $/$ ber $/$ tidak terjadi perubahan atau kekal. Pengekalan tersebut terjadi karena prefiks tersebut tidak melekat pada kata dasar ajar, serta kata dasar yang suku pertamanya berbunyi /er/.

\section{Morfofonemik Prefiks /me-/ (Konfiks me-kan dan me-i) pada Artikel Karangan Siswa.}

Morfofonemik prefiks /me-/ termasuk konfiks /me-kan/dan /me-i/ pada artikel karangan siswa kelas XII SMK Multimedia Tumpang terdiri dari kata merasa, melalui, melakukan, melaksanakan, meresahkan, merupakan, melaporkan, mengalami, menjaga, mencuci, mendeteksi, mempunyai, membiarkan, mengantarkan, mengikuti, menguasai, menghadapi, menggunakan, mencegah, menghindari, mempunyai, menciptakan, mengatur, memberikan, mengganggu, mendalam, mengidentifikasi, menghilangkan, menular, menyerang, memakai, memutuskan, menerima, menyenangkan, menyebabkan, menyentuh, menguasai, menyebabkan, menurun, mengurangi, memahami, menumpuk, menyebar, menerapkan, memutus. Proses afiksasi pada kata-kata tersebut menyebabkan perubahan, yaitu pengekalan fonem, penambahan fonem, dan peluluhan fonem. Contoh kata yang mengalami perubahan fonem pada prefiksasi /me-/ dan konfiks /me-kan / serta /me-i/ terdapat ada tabel di bawah ini.

Tabel 3. Morfofoemik prefiks /me-/ dan konfiks /me-kan /, /me-i/.

\begin{tabular}{|c|c|c|}
\hline $\begin{array}{l}\text { Perubahan } \\
\text { fonem }\end{array}$ & Kata & $\begin{array}{l}\text { Proses } \\
\text { bentukan }\end{array}$ \\
\hline \multirow[t]{6}{*}{ Pengekalan } & merasa & -me -rasa \\
\hline & memasuki & -masuk - i \\
\hline & & -me- \\
\hline & melakukan & masuki \\
\hline & & -laku-kan \\
\hline & & -me- \\
\hline \multirow[t]{2}{*}{ Penambahan } & menjaga & -meny- \\
\hline & & jaga \\
\hline
\end{tabular}

menggunakan -guna-kan -mengmenghindari gunakan

-hindar-i -menghindari

$\begin{array}{lll}\text { Peluluhan } & \begin{array}{l}\text { Menular } \\ \text { menyerang } \\ \text { memakai }\end{array} & \begin{array}{l}\text { me-tular } \\ \text { me-serang } \\ \text { me-pakai }\end{array}\end{array}$

Prefiksasi /me-/ dan konfiks /me-kan/, /me-i/ termasuk morfem yang produktif, hal ini terbukti dari banyaknya penggunaan morfem tersebut dalam artikel karangan siswa. Contoh kata yang mengalami pengekalan fonem pada tabel di atas terdapat pada kalimat berikut ini.

\section{Contoh 1}

Jangan ke luar rumah jika merasa kurang enak badan. (ar4/prg/3) Menyediakan posko pengecekan suhu badan untuk orang yang akan memasuki. Desa Ngadas.(ar2/prg/2) 


\section{Ada baiknya melakukan karantina. (ar4/prg/2)}

Contoh 1, pada kalimat pertama terdapat kata berafiks /me-/ yaitu kata merasa. Kata tersebut berasal dari kata dasar rasa dan mendapat tambahan prefiks /me-/. Penjabaran proses pembentukan katanya sebagai berikut, me + rasa = merasa. Perubahan pada bentukan kata tersebut, morfem /me-/ bersifat kekal atau tetap karena melekat pada kata dasar yang awalnya berfonem $\mid r /$. Kalimat kedua terdapat kata berklofiks /me-i /, yaitu kata memasuki. Kata tersebut berawal dari kata dasar masuk dan mendapat tambahan sufiks $/ i /$, sehingga menjadi kata masuki. Selanjutnya kata bersufiks tersebut mendapatkan prefiksasi /me-/, sehingga menjadi kata memasuki. Klofiks merupakan golongan afiks yang pengafiksasiannya dilakukan secara bertahap (Chaer, 2008). Sehingga proses bentukan tersebut jika dijabarkan sebagai berikut,

$$
\begin{aligned}
& \text { masuk }+i=\text { masuki } \\
& \text { me }+ \text { masuki }=\text { memasuki }
\end{aligned}
$$

Sama halnya dengan kalimat ketiga terdapat kata berklofiks /me-kan/ yaitu kata melakukan. Kata tersebut berawal dari kata dasar laku, serta mendapat sufiks /i/ dan menjadi kata patuhi. Lalu kata bersufiks tersebut mendapat prefiksasi /me-/ dan menjadi kata melakukan. Tahapan proses bentukan tersebut bila dijabarkan sebagai berikut.

$$
\begin{aligned}
& \text { laku }+ \text { kan = lakukan } \\
& \text { me + lakukan = melakukan }
\end{aligned}
$$

perubahan fonem pada kalimat kedua dan ketiga juga mengalami pengekalan fonem. Morfem /me-/ pada proses afiksasi tersebut melekat ada kata dasar yang awalnya $/ \mathrm{m} / \mathrm{dan} / \mathrm{l} /$.

Prefiksasi /me-/ dan klofiks /mekan/ serta /me-i/ menyebabkan penambahan fonem. Contoh kata yang mengalami penambahan fonem pada tabel di atas terdapat dalam kalimat berikut ini.

\section{Contoh 2}

Selalu menjaga jarak aman
dengan yang batuk atau
bersin.(ar4/prg/4)
Pencegahan covid 19 bisa dengan
menggunakan ( $\operatorname{ar} 8 / \mathrm{prg} / 3)$

Menghindari kontak dekat dengan pasien.(ar8/prg/4)

Contoh 2 pada kalimat pertama, terdapat kata yang mengalami penambahan fonem nasal /ny/ pada prefik /me-/ yaitu kata menjaga. Kata bentukan tersebut berasal dari kata dasar jaga yang mendapat prefiksasi /meny-/. Berikut penjabaran proses bentukan katanya.

meny + jaga = menyjaga . Penambahan fonem nasal $/ n y /$ pada prefiks /me-/, disebabkan oleh morfem /me-/ melekat pada kata dasar yang di awali dengan fonem $/ j /$.

Kalimat kedua dan ketiga, terdapat kata yang mengalami penambahan fonem nasal /ng/ pada prefiks /me-/ yaitu kata menggunakan dan kata menghindari. Kata tersebut berasal dari kata dasar guna yang mendapat tambahan klofiks /me-kan/ dan kata hindar yang mendapatkan tambahan klofiks /me-i/. Berikut penjabaran proses bentukan klofiks pada kata tersebut,

$$
\begin{aligned}
& \text { guna }+ \text { kan }=\text { gunakan } \\
& \text { meng }+ \text { gunakan }=\text { menggunakan } \\
& \text { hindar }+i=\text { hindari } \\
& \text { meng }+ \text { hindari }=\text { menghindari }
\end{aligned}
$$

Penambahan fonem nasal $/ \mathrm{ng} /$ disebabkan karena morfem /me-/ melekat pada kata dasar yang diawali dengan fonem /g/ dan /h/. Sehingga kata yang benar bukan megunakan namun menggunakan atau bukan mehindari namun yang benar menghindari.

Prefiksasi /me-/ juga dapat menyebabkan peluluhan fonem. Peluluhan fonem disebabkan karena prefiks tersebut melekat pada kata dasar yang diawali dengan fonem tertentu. Contoh kata yang mengalami peluluhan fonem terdapat dalam kalimat berikut ini.

\section{Contoh 3}


Virus ini menular melalui percikan dahak. (ar4/prg/2)

Penularan melalui percikan dahak yang menyerang saluran pernapasan. (ar4/prg/5)

Tetap memakai masker saat keluar rumah. (ar4/prg/6)

Contoh 3, pada kalimat pertama terdapat kata yang mengalami peluluhan fonem, yaitu kata menular yang berasal dari kata dasar tular dan mendapat tambahan prefiks /me-/. Proses bentukan katanya dijabarkan sebagai berikut, me + tular $=$ menular . Bentukan kata tersebut menyebabkan peluluhan fonem / $t /$ pada kata dasar tular yang digantikan dengan fonem nasal $/ n /$ sehingga yang benar bukan kata metular tetapi kata 'menular'.

Kalimat kedua terdapat kata menyerang yang berasal dari kata dasar serang yang mendapat tambahan prefiks /me-/. Proses bentukan katanya dijabarkan sebagai berikut,

$$
\text { me }+ \text { serang }=\text { menyerang }
$$

Bentukan kata tersebut menyebabkan peluluhan fonem /s/ pada kata dasar serang yang digantikan dengan fonem nasal /ny/. Sehingga yang benar bukan kata meserang namun kata menyerang. Kalimat ketiga terdapat kata memakai yang berasal dari kata dasar pakai yang mendapat tambahan prefiks /me-/. Proses bentukan tersebut dijabarkan sebagai berikut, me + pakai $=$ memakai . Proses bentukan tersebut menyebabkan peluluhan fonem / $p /$ pada kata dasar pakai yang digantikan dengan fonem nasal $/ \mathrm{m} /$. Sehingga yang benar bukan kata mepakai namun kata memakai.

Morfofonemik Prefiks /pe-/ dan konfiks /pe-an/ pada Artikel Karangan Siswa.

Morfofonemik prefiks /pe-/ dan konfiks /pe-an/ yang terdapat pada artikel karangan siswa kelas XII SMK Multimedia Tumpang yaitu kata pemusnahan, pencegahan, pengangkutan, pengawasan, pendatang, penyelidikan, pembatasan, penyakit, penularan, penyebaran, penyedia, penyebab, peningkatan, pengelolaan, pengumpulan, penanganan, pengendalian. Proses afiksasi pada kata-kata tersebut menyebabkan perubahan yaitu penambahan fonem, peluluhan fonem. Namun tidak ditemukan pengekalan fonem. Contoh kata yang mengalami perubahan fonem pada prefiks /pe-/ dan konfiks /pe-an/ terdapat dalam tabel berikut ini.

Tabel 4. Morfofonemik prefiks /pe-/ dan konfiks /pe-an/.

\begin{tabular}{|c|c|c|}
\hline $\begin{array}{l}\text { Perubahan } \\
\text { fonem }\end{array}$ & kata & $\begin{array}{l}\text { Proses } \\
\text { bentukan }\end{array}$ \\
\hline Penambahan & $\begin{array}{l}\text { pencegahan } \\
\text { pendatang } \\
\text { pembatasan }\end{array}$ & $\begin{array}{l}\text { peny- } \\
\text { cegah-an } \\
\text { pen- } \\
\text { datang } \\
\text { pem- } \\
\text { batas-an }\end{array}$ \\
\hline peluluhan & $\begin{array}{l}\text { penyakit } \\
\text { penanganan } \\
\text { pengendalian }\end{array}$ & $\begin{array}{l}\text { pe-sakit } \\
\text { pe- } \\
\text { tangan-an } \\
\text { pe- } \\
\text { kendali- } \\
\text { an }\end{array}$ \\
\hline
\end{tabular}

Perubahan pada prefiksasi / $/ \mathrm{pe} / \mathrm{dan}$ konfiksasi /pe-an/ pada tabel 4, terdapat pada contoh kalimat di bawah ini.

\section{Contoh 1}

Pencegahan virus korona adalah sering-sering mencuci tangan. (ar4/prg/4)

Saat pendatang akan memasuki Desa Ngadas terlebuh dahulu mereka akan melewati posko.(ar2/prg/2)

$\begin{array}{lrr}\text { Kenakan masker jika } & \\ \text { pembatasan } & \text { fisik tidak }\end{array}$ memungkinkan. (ar8/prg/4)

Contoh 1, kalimat pertama terdapat penambahan fonem /pe-an/ yaitu kata pencegahan. Pada kata tersebut konfiksasi /pe-an/ mengalami penambahan fonem 
nasal /ny/. Kata pencegahan berasal dari kata dasar cegah dan mendapat tambahan konfiks /peny-an/. Bentukan kata tersebut bila dijabarkan adalah sebagai berikut, peny + cegah + an = penycegahan

Proses bentukan tersebut menyebabkan penambahan fonem nasal $/ n y /$, karena morfem /pe-an/ melekat pada kata dasar yang diawali dengan fonem $/ c /$ yaitu kata cegah.

Kalimat kedua terdapat kata pendatang. Proses konfiksasi pada kata tersebut menyebabkan penambahan fonem nasal $/ n /$ pada prefiks /pe-/. Kata pendatang berasal dari kata dasar datang, yang mendapat tambahan prefiks /pen-/ sehingga jika dijabarkan sebagai berikut,

$$
\text { pen }+ \text { datang }=\text { pendatang }
$$

Proses penambahan fonem nasal $/ n /$, karena morfem /pe-/ mengikuti kata dasar yang berawal fonem /d/ yaitu kata datang. Kalimat ketiga terdapat perubahan fonem pada kata pembatasan. Kata tersebut berasal dari kata dasar batas dan mendapatkan penambahan konfiks /pean/. Konfiksasi pada proses tersebut menyebabkan penambahan fonem nasal $/ \mathrm{m} /$ sehingga apabila dijabarkan sebagai berikut,

$$
\text { pem }+ \text { batas }+ \text { an = pembatasan }
$$

penambahan fonem nasal $/ \mathrm{m} /$, karena morfem /pe-an/ mengikuti kata dasar dengan fonem awal $/ b /$ yaitu kata batas.

Peluluhan fonem /pe-/ dan /pe-an/ pada kata dalam tabel 4 terdapat pada kalimat berikut ini.

\section{Contoh 2}

Penyakit karena infeksi virus ini disebut covid-19.(ar7/prg/1)

Harus secepatnya melakukan penanganan agar virus tidak menyebar. (ar2/prg/1)

Tingkatkan standar praktik pencegahan dan pengendalian infeksi d rumah sakit (ar2/prg/4).
Contoh 2, kalimat pertama terdapat perubahan pada kata penyakit. Kata tersebut berasal dari kata dasar sakit, dan mendapat tambahan prefiks /pe-/. Penjabaran bentukan kata tersebut dipaparkan sebagai berikut,

$$
\text { pe }+ \text { sakit }=\text { penyakit } \text {. }
$$

Bentukan kata tersebut menyebabkan peluluhan fonem $/ s /$ pada kata dasar sakit, dan digantikan dengan fonem nasal /ny/. Peluluhan fonem disebabkan karena morfem / pe-/ mengikuti kata dasar yang di awali dengan fonem $/ s /$.

Kalimat kedua, terdapat perubahan pada kata penanganan. Kata tersebut berawal dari kata dasar tangan yang mendapat tambahan konfiks /pe-an/. Penjabaran bentukan kata tersebut dipaparkan sebagai berikut,

pe + tangan + an = penanganan

Pembentukan kata tersebut menyebabkan peluluhan fonem /t/ pada kata dasar tangan, dan digantikan dengan fonem nasal $/ n /$. Peluluhan fonem tersebut disebabkan karena morfem /pe-an/ mengikuti kata dasar yang di awali dengan fonem $/ t /$. Sama halnya dengan kalimat ketiga, terdapat perubahan pada kata pengendalian. Kata tersebut berawal dari kata dasar kendali yang mendapat tambahan konfiks /pe-an/. Berikut ini penjabaran bentukannya,

$$
\text { pe }+ \text { kendali }+ \text { an }=\text { pengendalian }
$$

Proses pembentukan kata tersebut menyebabkan peluluhan fonem $/ \mathrm{k} /$ pada kata dasar kendali yang digantikan dengan fonem nasal $/ n g /$ Peluluhan tersebut disebabkan karena morfem /pe-an/ mengikuti kata dasar yang di awali dengan fonem $/ k /$.

Morfofonemik Prefiks /per-/ dan
Konfiks /per-an/ pada Artikel
Karangan Siswa
Perubahan fonem pada proses
prefiksasi/per-/ dan konfiksasi /per-an/
pada artikel karangan siswa kelas XII
SMK Multimedia Tumpang yaitu kata


perawatan, pernapasan, perjalanan, permukaan, perhatian, peringkat. Proses afiksasi kata-kata itu menyebabkan pelepasan fonem dan pengekalan fonem, namun tidak ditemukan perubahan fonem.. Contoh kata yang mengalami perubahan pada prefiks /per-/ dan konfiks /per-an/terdapat dalam tabel berikut ini.

Tabel 5. Morfofonemik prefiks /per-/ dan konfiks/per-an/.

\begin{tabular}{lll}
\hline $\begin{array}{l}\text { Perubahan } \\
\text { fonem }\end{array}$ & kata & $\begin{array}{l}\text { Proses } \\
\text { bentukan }\end{array}$ \\
\hline pelepasan & perawatan & $\begin{array}{l}\text { per-rawat- } \\
\text { an }\end{array}$ \\
\hline pengekalan & Perlindungan & $\begin{array}{l}\text { per- } \\
\text { lindung-an } \\
\end{array}$ \\
& permukaan & $\begin{array}{l}\text { per-muka- } \\
\text { an }\end{array}$
\end{tabular}

Pelepasan fonem pada proses
afiksasi /per/ dan konfiksasi /per-an/, terdapat pada kalimat berikut ini.

\section{Contoh 1}

Perawatan medisnya yaitu isolasi mandiri dan hubungi penyedia layanan kesehatan covid 19. (ar7/prg/3)

Contoh 1, pada kalimat tersebut terdapat perubahan pada kata perawatan. Kata tersebut berawal dari kata dasar rawat, yang mendapat tambahan konfiksasi /per-an/. Bila dijabarkan proses tersebut sebagai berikut,

$$
\text { per- + rawat }+ \text { an = perawatan }
$$

Proses bentukan tersebut menyebabkan pelepasan fonem nasal $/ r /$ pada morfem /per-an/. Pelepasan tersebut karena morfem /per-an/ mengikuti kata dasar rawat yang di awali dengan fonem $/ r /$.

Pengekalan fonem pada prefiksasi /per-/ dan konfiksasi /per-an/ pada kata di tabel 5, terdapat dalam kalimat berikut ini.

\section{Contoh 2}

Menghindari kontak dengan orang lain tanpa ada perlindungan. (ar8/prg/4/)

Kita bisa tertular setelah menyentuh permukaan benda- benda yang terkena percikan doplex kemudian menyentuh hidung atau mulut. (ar8/prg/2)

Contoh 2, pada kalimat pertama dan kedua terdapat perubahan pada kata perlindungan dan kata permukaan. Kata tersebut berawal dari kata dasar lindung dan kata dasar muka yang mendapat tambahan konfiks /per-an/. bila dijabarkan proses tersebut berikut ini,

$$
\begin{aligned}
& \text { per }+ \text { lindung }+ \text { an }=\text { perlindungan } \\
& \text { per }+ \text { muka }+ \text { an }=\text { permukaan }
\end{aligned}
$$

Bentukan tersebut menyebabkan pengekalan pada morfem /per-an/. Pengekalan terjadi karena morfem tersebut mengikuti kata dasar lindung dan muka yang diawali dengan fonem $/ / /$ dan $/ \mathrm{m} /$.

\section{Morfofonemik prefiks /ter-/ pada Artikel Karangan Siswa}

Perubahan fonem pada proses prefiksasi /ter-/ dalam artikel karangan siswa kelas XII SMK Multimedia Tumpang hanya terdapat pengekalan fonem /ter-/ yaitu kata terdampak, terpapar, termasuk, terhubung, terinfeksi, terpencil, tersebut, terkena, terkait, terlaksana, terhenti, terutama, tertular, terbanyak, terbukti, terbaru. Belum ditemukan pelesapan fonem dan perubahan fonem. Berikut contoh kata dalam tabel yang mengalami pengekalan fonem /ter-/

Tabel 6. Morfofonemik prefiks /ter-/

Perubahan kata Proses

fonem bentukan

Pengekalan terinfeksi ter-infeksi

fonem

Perubahan prefiksasi /ter-/ pada kata di tabel 6, terdapat dalam kalimat berikut ini,

\section{Contoh 1}

Seseorang dapat tertular dari penderita covid 19.(ar8/prg/2) Tanda-tanda orang terpapar virus korona. ( $\operatorname{ar} 2 / \mathrm{prg} / 3)$ 
Contoh 1, kalimat pertama dan kedua terdapat perubahan fonem pada kata tertular dan kata terpapar. Kata-kata tersebut berawal dari kata dasar tular dan kata papar yang mendapat tambahan prefiks /ter-/. Penjabaran bentukan tersebut dipaparkan berikut ini,

$$
\begin{aligned}
& \text { ter }+ \text { tular }=\text { tertular } \\
& \text { ter }+ \text { papar }=\text { terpapar }
\end{aligned}
$$

Bentukan kata tersebut menyebabkan morfem /ter-/ tidak mengalami perubahan atau bersifat kekal. Hal tersebut dikarenakan morfem /ter-/ mengikuti kata dasar yang diawali dengan fonem $/ t /$ dan $/ p /$ pada kata dasar tular dan kata papar.

\section{Kerancuan Morfofonemik pada Artikel Karangan Siswa. \\ Kerancuan morfofonemik merupakan kesalahan pembubuhan fonem karena tidak sesuai dengan kaidah yang sudah ditentukan. Kerancuan morfofonemik pada artikel karangan siswa kelas XII SMK Multimedia Tumpang disebabkan karena ketidaktelitian siswa dalam menuliskan kata bermorfofonemik. Berikut tabel kerancuan morfofonemik dalam artikel karangan siswa. \\ Tabel 7. Kerancuan Morfofonemik}

\begin{tabular}{lll}
\hline $\begin{array}{l}\text { Fonem yang } \\
\text { rancu dal- } \\
\text { am artikel }\end{array}$ & $\begin{array}{l}\text { Penulisan } \\
\text { yang benar }\end{array}$ & Kata dasar \\
\hline berpergian & bepergian & Pergi \\
\hline $\begin{array}{l}\text { Mengon- } \\
\text { firmasi }\end{array}$ & $\begin{array}{l}\text { Mengkon- } \\
\text { firmasi }\end{array}$ & $\begin{array}{l}\text { Konfirmas } \\
\text { i }\end{array}$ \\
\hline bersentuan & bersentuhan & Sentuh \\
& & \\
\hline $\begin{array}{l}\text { Mengkonsums } \\
\text { i mengonsums }\end{array}$ & konsumsi \\
\hline menyakup & mencakup & Cakup \\
\hline \multicolumn{3}{c}{ Kerancuan pada kata berpergian, } \\
karena tidak lesapnya fonem nasal /r/ \\
pada kata yang suku pertama bentuk \\
dasarnya berbunyi /er/. Kerancuan pada
\end{tabular}

kata mengonfirmasi, karena terjadi peluluhan fonem $/ k /$ pada kata dasar konfirmasi. Peluluhan tidak perlu terjadi karena morfem /me-/ melekat pada kata dasar yang di adopsi dari bahasa asing yaitu bahasa inggris 'confirmation'. Kesalahan pada kata bersentuan, karena fonem $/ h /$ pada kata dasar sentuh tidak perlu dihilangkan karena adanya proses konfiksasi /ber-an/. Kesalahan pada kata mengkonsumsi, karena tidak luluhnya fonem $/ k$ / saat proses klofiksasi /me-kan/ yang seharusnya luluh atau hilang dan digantikan dengan fonem nasal /ng/. Kerancuan pada kata menyakup karena luluhnya fonem /c/ pada kata dasar cakup yang seharusnya tidak luluh.

\section{KESIMPULAN}

Morfofonemik pada artikel karangan siswa kelas XII SMK Multimedia Tumpang terdiri dari penambahan fonem, pelesapan fonem, peluluhan fonem, perubahan fonem, serta pengekalan fonem, Proses afiksasi yang mengakibatkan perubahan fonem yaitu, pada prefiksasi /ber-/. Prefiksasi /me-/ dan klofiksasi /me-kan/, /me-i/. Prefiksasi /pe-/ dan konfiksasi /pe-an/. Prefiksasi /per-/ dan konfiksasi /per-an/. Prefiksasi /ter-/. Ditemukan Kerancuan morfofonemik sebanyak 5 kata, serta tidak ditemukan perubahan fonem pada proses sufiksasi /an/.

Peneliti melihat penguasaan materi menulis artikel oleh siswa kelas XII SMK Multimedia Tumpang sudah sangat bagus. Hal tersebut terlihat dari penulisan kata yang sudah sesuai dengan kaidah Tata Bahasa Indoensia, salah satunya adalah pengaplikasian proses morfofonemik yang tepat dan pas pada setiap katanya, serta minimnya kesalahan penulisan kata pada proses perubahan fonem tersebut.

\section{DAFTAR PUSTAKA}

Abidin, Y. (2019). Konsep Dasar Bahasa Indonesia - Google Buku. Jakarta: 
Al Muthi'ah, A. K. dan S. (2019). Morfofonemik Dalam Teks Pidato Karangan Siswa Kelas XII SMK Negeri 1 Durenan. Basindo, 3(1), 7584. https://doi.org/10.1088/1751$8113 / 44 / 8 / 085201$

Alex. (2018). Linguistik Umum. In $P T$ Gelora Aksara Pratama. PT Gelora Aksara Pratama.

Alexandria, R. (2016). Proses Morfofonemik Kata Berafiks Dalam Rubrik Percikan Majalah Gadis (Skripsi). Surakarta: Universitas Sebelas Maret, 1-145.

Arifin, Z. dan J. (2017). Morfologi. Grasindo.

Bloomfield, L. (1995). Bahasa (Language) - Google Buku. London: George Allen and Unwin Ltd.

Chaer, A. (2008). Morfologi Bahasa Indonesia (pendekatan Proses). In Jakarta: Rinneka Cipta. Rineka Cipta.

Fatmawati, D. (2014). Analisis Morfofonemik Novel Kidurakan ing Kidul Drangu Karya Suparti Brata. 01, 63-68.

Hasan, A. dan D. S. (2002). Telaah bahasa dan sastra: persembahan kepada Prof. Dr. Anton M. Moeliono ( alwi Hasan (ed.); 1st ed.). Pusat
Pengembangan dan Pembinaan Bahasa.

Ingguoe, S. L. Y. (2015). Tata Bahasa Rote. In Deepublish (Vol. 237). DEEPUBLISH.

Mutiadi, D. A. dan I. P. (2015). Analisis Kesalahan Morfologi dan Sintaksis pada Pidati Presiden Joko Widodo Periode Januari 2015. Fon: Jurnal Pendidikan Bahasa Dan Sastra Indonesia, 13(3), 1576-1580.

Parera, J. D. (2007). Morfologi bahasa (4th ed.). PT Gramedia Pustaka Utama.

Paryono, Y. (2018). Morfofonemik bahasa Jawa dialek Surabaya. Widyariset, 173-181.

https://doi.org/http://dx.doi.org/10.14 203/widyariset.13.1.2010.173-181

Rizky, A. S. (2019, August). Kata: Pengertian, Tujuan, Fungsi, Jenis, Bentuk, dan Contoh Lengkap. FA Bahasa.

Wijaya, F. P. R. (2020). Morfofonemik Kata Benda dan Kata kerja Bahasa Jawa Dialek Surabaya dalam Acara Pojok Kampung JTV (thesis). IRPerpustakaan Universitas Airlangga, 1-79.

Yusuf, A. M. (2017). Metode Penelitian Kuantitatif, Kualitatif \& Penelitian Gabungan. Kencana. 